\title{
Epistulam versibus clusero: Fluid Paratextuality in Martial's Prose Prefaces
}

\section{Introduction}

The beginning of any work is liminal and difficult to define. In the case of Martial's Epigrams, however, where beginnings occur at the start (and end) of every poem, each book constitutes a riot of beginnings and endings that make it even harder to specify whether the text ever truly starts or finishes. The Epigrams are infamous for their organised chaos, in which the themes from individual poems seem to bleed from one epigram to the next. ${ }^{1}$ The effect of this thematic fluidity on Martial's prose prefaces, which are found preceding five of his twelve books of the Epigrams (books 1, 2, 8, 9 , and 12), however, has not yet been analysed fully. ${ }^{2}$ While these prefaces explicitly situate themselves somewhere beyond the text, they also frustrate a straightforward view of their paratextuality (i.e. their conceptual and physical separation from the main body of the text) by their inclusion of prefatory poems, or their engagement with specific themes that recur throughout the text they precede. ${ }^{3}$ In this paper, I argue that the materiality of these texts influences their interpretation, and that changes to the format of the physical text can have profound effects on its reception. Every transition of the text from papyrus scroll to codex (whether ancient or modern), from manuscript to the supposedly tidy critical edition (and now onwards towards ebook technology), brings with it a change to the text's layout and presentation, each time altering how the reader perceives the exact beginning of the book and the end of the paratext.

That the paratext is a difficult concept to pin down is due (in part) to its status as a liminal textual object. For Genette, the paratext represents to its reader "an 'undefined zone' [...] without any hard and fast boundary on either the inward side (turned toward the text) or the outward side (turned toward the world's discourse about the text)." ${ }^{4}$ What complicates the paratextuality of prefatory letters is their inward and outward facing nature. Such paratexts, which Genette names "peritexts" for their

1 See esp. Fitzgerald 2007, 80.

2 Johanssen 2006's comparison of Martial's Epigrams and Statius' Silvae does a good job exploring the role of the preface in both authors, but tends to see the preface as an entity that is entirely distinct from the text itself.

3 On the paratext, see Genette 1997, 2. For an overview of the paratext and its place in Latin philology, see Jansen 2014. Parker 2014, 116-117 and 126-128 briefly compares Statius' prefaces with Martial's, but he focuses more on the prefaces' attempts to address the diversity of the text's potential audiences than on their structural liminality.

4 Genette 1997, 2. Cf. Jansen 2014, 5: "Paratexts are neither fully attached to nor detached from the text, but they conform to a liminal zone between its inside and outside.”

Ә Open Access. ( 2019 Sam A. Hayes, publiziert von De Gruyter. (c) BY-NC-ND Dieses Werk ist lizenziert unter der Creative Commons Attribution-NonCommercial-NoDerivatives 4.0 Lizenz.

https://doi.org/10.1515/9783110641042-008 
physical attachment to the text itself, place an even greater strain on their liminality because they are deeply intertwined with a text from which they nevertheless claim a degree of separation. ${ }^{5}$ While the nature of all peritextual prefaces complicates their conceptual liminality, Martial's placement of prefatory epigrams within these letters (e. g. 1 praef. ep. and 9 praef. ep.) serves to problematize the distinction between paratext and text. ${ }^{6}$ Furthermore, Martial's prose prefaces already exhibit a "fluid paratextuality" - whereby they shift constantly between a textual and paratextual relationship with the main text - but this fluidity is further enhanced by the changes to the material text that have taken place over the past two thousand years, and which make these liminal borders less distinct.

Although Martial frequently blurs the boundary between text and preface, it is clear that he still considered his prose prefaces to be paratextual objects. Indeed, Martial makes this explicit in his preface to book 9 when he states that the epigram immediately following the preface is extra ordinem paginarum (Mart. 9 praef. 1-2)-beyond the series of columns on the papyrus scroll. ${ }^{7}$ Similarly, in his second preface Martial comments that readers who make their way through this letter "will not come through to the first column (ad primam paginam) worn out" (Mart. 2 praef. 15-16). ${ }^{8}$ For Martial, the preface is situated physically and conceptually in a zone in front of the first column of the text (as depicted in fig. 1). This conceptual distinction between preface and text is further reinforced by the prefaces' description as epistulae (letters), an entirely different genre of writing to the epigrams his readers expect upon opening the book. ${ }^{9}$ The status of these prefaces as prose letters, rather than verse introductions, also visually differentiates Martial's text from its paratext. Prose was laid out on the scroll in rigid columns with an equal width preserved by the scribe, while verse texts featured a varied indentation and layout dependent upon the metrical form; pentameter lines were indented, for instance, and paragraphoi divided the poems from one another, as can be seen on the famous Gallus fragment. ${ }^{10}$ By positioning its prefaces extra or-

5 Genette 1997, 5. "Peritexts" are paratexts physically attached to the text (e. g. prefaces, chapter titles, and footnotes such as this), while "epitexts" are paratexts physically separated from the text (e.g. authorial blogs, reviews, and private communications concerning the text).

6 I have adopted the shorthand 'praef. ep.' throughout this paper to refer specifically to epigrams found within the borders of Martial's prefaces.

7 Mart. 9 praef. 1-2: epigramma, quod extra ordinem paginarum est. The text and numeration of Martial I use comes from Shackleton Bailey 1990. N. B. While there is archaeological evidence of codices existing at the turn of the second century AD (P. Oxy. 30 is a good example), I find Martial's continuous reference to material features of the bookroll (such as its umbilici at 3,2,9 and 4,89,2 or its cornua at $11,107,1)$ a compelling reason to read Martial as a poet writing for the bookroll form rather than the codex. On the codex/bookroll debate, see Blake 2014.

8 Mart. 2 praef. 15-16: ad primam paginam non lassi pervenient. Cf. Mart. 8 praef. 19, where he states that 8,1 is an epigram on the very border (limen) of the libellus. I discuss this epigram and its position outside the preface below.

9 Mart. 1 praef. 15 and 20; 2 praef. 1, 4, 7 and 13.

10 Johnson 2004, 129. For the Gallus fragment, see Anderson/Parsons/Nisbet 1979, plate IV. 
dinem paginarum, Martial's physical text enforced (and embodied) a conceptual divide between text and paratext, even though the prefaces' content invites the reader to question exactly what constitutes text.

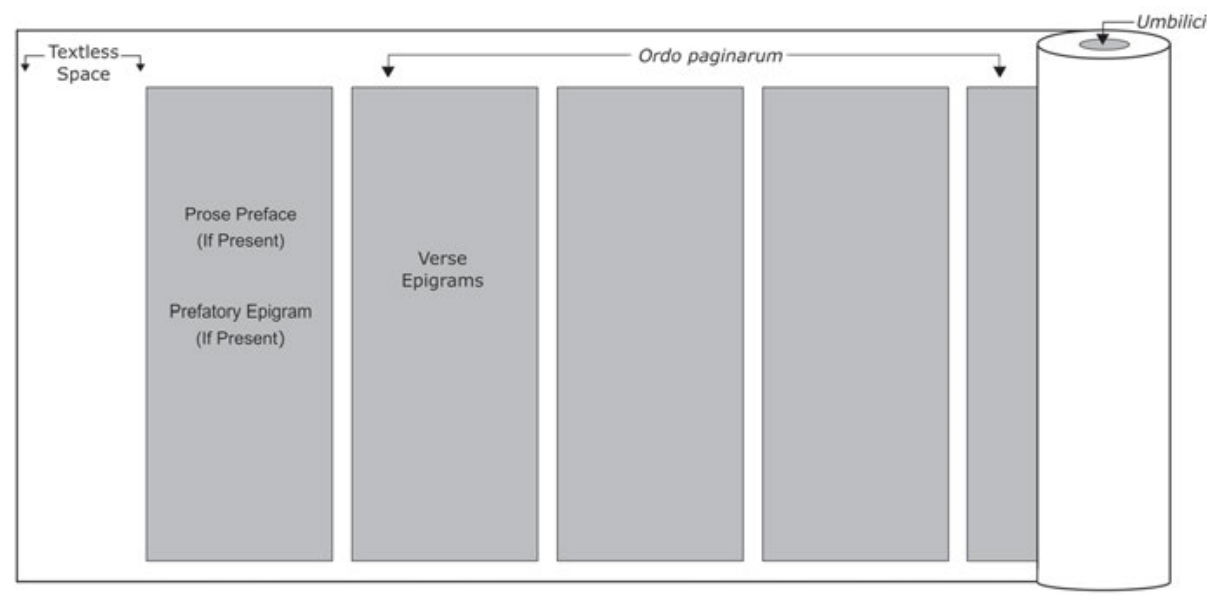

Fig.1: A reconstruction of the prose preface's physical location in the bookroll @ Sam A. Hayes.

It is also clear from a comparison with other ancient preface writers that the ancient preface was generally kept separate from the main body of the book to reinforce this conceptual divide. Statius, one of Martial's contemporaries, stands as a fellow innovator in attaching prose prefaces to the verse text of his Silvae. ${ }^{11}$ While his prefaces do not discuss their own purpose as explicitly as Martial's, they do take a distant tone when describing the poems in the book, providing the social context of the work that follows and establishing the order of the poems, which in turn reinforces the letters' own position beyond the text proper. By describing a poem as the "first" item in the book, these paratexts conceptually distance themselves from their text. ${ }^{12}$ In both these cases, Statius (unlike Martial) is careful to create a distinct paratextual separation between his paratext and his text, despite the peritextual closeness of the prefaces to the poems they introduce, and to promote a more rigid sense of textual unity than the epigrammatist. ${ }^{13}$ While Statius implicitly reinforces the conceptual paratextuality of his prefaces, one of Cicero's letters exhibits a more overtly physical distancing of the preface from the text. Writing to Atticus, Cicero states that he attached the

11 For a history of the prose preface in antiquity and Martial and Statius' innovation of the form, see Janson 1964, 106-112.

12 Stat. silv. 1 praef. 16; 2 praef. 4; 3 praef. 9; 4 praef. 5. On this ordering see Newlands 2009, $239-240$. 13 Parker 2014, 127. Parker provides a decent survey of Statius' prefaces, and remarks (pp. 116-117) on the variety of Martial's prefaces in contrast. I would argue that the variety in Martial's prefaces reflects the key themes (and individuality) of the books they precede. 
wrong preface (which he terms a prohoemium) to the front of his (now lost) treatise De gloria, which he had already used in another work, and asks his friend to rip it out and paste in a different one from a book of prohoemia that Cicero keeps handy. ${ }^{14}$ The interchangeability of Cicero's prohoemia here is particularly telling, and the physical separation of text and paratext is implied; a prohoemium could not be removed and replaced easily without the main text of the De gloria beginning on a subsequent pagina. For Cicero, too, the prohoemium does not even have to be directly composed with the text in mind. Martial's prefaces are more intricately linked to the book's central themes than Cicero's prohoemia, but they are marked out as being somehow beyond the borders of the text despite their physical proximity. Even though Martial thematically interweaves his prefaces with his text, he still represents his introductory letters as paratextual objects.

Martial's prefaces offer the reader a paratextual paradox. Although they describe themselves as being extra ordinem paginarum, and although the physicality of the text reinforces this conceptual separation, they also blur the borders between text and paratext by engaging with their book's overarching themes. As the next section demonstrates, the prefaces to Epigrams 1 and 9 both problematize the concept of the preface as a separate paratextual entity, questioning the idea of the paratext's own paratextuality by providing the reader with an epigram before they reach the ordo paginarum. In this way, Martial already textualises the paratext, and paratextualises his text, drawing the preface into the never-ending chain of texts that constitutes his Epigrams as an oeuvre. As I demonstrate in the latter half of this paper, however, Martial's own interplay with boundaries relies on the physicality of the text, and when that physicality is altered (as in the case of books 2 and 8), the paratextuality of his prefaces is brought even further into question. Martial's experimentation with his prefaces' paratextuality encourages the reader to reconsider what exactly constitutes a text, but reconstituting the material text can also encourage the reader to question the exact (para)textuality of these prefatory letters.

\section{Where to Begin? Shifting (Para)textual Borders in Martial's Prefaces}

Despite stating that his prefaces are extra ordinem paginarum, Martial often problematizes their separation from the main text of his Epigrams by including a poem within their borders. These 'prefatory epigrams' threaten to collapse the boundary between text and paratext, and force the reader to question where the book itself officially begins. The preface to book 9 perhaps best exhibits Martial's playful engagement with

14 Cic. Att. 16,6,4. 
the materiality of his libellus, as it buries its prefatory epigram within a poem that is itself located within a prose letter:

Have, mi Torani, frater carissime. Epigramma, quod extra ordinem paginarum est, ad Stertinium clarissimum virum scripsimus, qui imaginem meam ponere in bibliotheca sua voluit. De quo scribendum tibi putavi, ne ignorares Avitus iste quis vocaretur. Vale et para hospitium.

Note, licet nolis, sublimi pectore vates, cui referet serus praemia digna cinis,

hoc tibi sub nostra breve carmen imagine vivat, quam non obscuris iungis, Avite, viris:

'ille ego sum nulli nugarum laude secundus quem non miraris, sed, puto, lector, amas.

Maiores maiora sonent: mihi parva locuto sufficit in vestras saepe redire manus.'

Hail, my Toranius, dearest brother! I have written an epigram, which stands outside the series of columns, to the very famous gentleman, Stertinius, who wanted to place my likeness in his library. I thought I should write about him to you, so you would not be ignorant of this Avitus who is invoked. Farewell and prepare a welcome.

A bard known, though you don't want it, for his sublime inspiration, To whom late ashes will bring worthy rewards, May this short song live under my likeness for you, Which, Avitus, you join with men not obscure:

'I am he, second to none in praise of my trifles Whom you do not admire but I think, reader, you love. Let greater men sound greater things: It suffices me, After saying small ones, to return often to your hands.' (Mart. 9 praef.)

In this preface and its prefatory epigram Martial explores ideas about the materiality and textuality of his poetry. The prose section of the preface describes the reason for the following poem's existence (its placement in Stertinus Avitus' library), after which the prefatory epigram introduces the poem it quotes, which in turn provides the words to be inscribed beneath the poet's bust in the library. The reader, however, encounters this poem not beneath a statue, but inside a poetry book, which amplifies the existence of Avitus' statue of the poet while usurping its role as a purveyor of the epigrammatist's fame. The statue in the library commemorates the poet's fame and poetic significance, but the poem in the book commemorates the statue itself.

Such one-upmanship is standard for Martial, but the poet further complicates his playful depiction of poetry's immaterial dominance over a statue's material ephemerality by punning on the very concept of a commemorative imago. ${ }^{15}$ This statue (imago)

15 On Martial's proliferation of the concept of Horace's poetic monument via Ovid, see Roman 2001, 123-124. 
takes on the role of the painted image of the poet (imago, e. g. Mart. 7,84,1) that might sit at the front (extra ordinem paginarum) of a text that was sent to a favoured patron. By punning on an imago at the opening of book 9, Martial highlights the commemorative power of both imagines (statue and painting) and redirects them into his own textual commemoration. For the reader of the book-a bizarre addressee for a poem found on a statue, as Henriksén acknowledges-there is no statue to be seen, nor any library, only the written/printed text on the page. ${ }^{16}$ Furthermore, the invisibility of this imago is paralleled by the invisibility of Martial's friends and Avitus' librarywhile the poet is a notus vates (Mart. 9 praef. ep. 1) and is included amongst the poets deemed not obscure (4), he has to explain the identity of the supposedly clarissimus (but evidently not-famous-enough) Stertinus Avitus to Toranius, an equally unknown figure in this preface. ${ }^{17}$ The known poet is commemorated by an unknown friend of an equally minor friend, so the famous figure ensures that this act of (self-)preservation is recorded for all to see. ${ }^{18}$ Martial's preface thus questions the material nature of its prefatory epigram's existence beyond the text in the form of a (possibly fictive) bust at Avitus' library. This in turn prepares the reader for further metapoetic posturing within book 9's subsequent collection of statue poems, and frustrates the similarly material boundary between this prefatory poem and the epigrams in the book.

This prefatory epigram, poem, and letter all serve to highlight the connection of the paratext with the text it precedes, even as their paratextuality denies such a union. Significantly, the statue's poem is wrapped in a text that marks it out as a component of the book: the poem is buried within a text that is buried within a paratext, as the poet himself states, and he privileges the poem's appearance here extra ordinem paginarum before he explains its original location in Stertinus' library (in bibliotheca sua) a few words later. Before Martial's reader even reaches the threshold of the main text, they are frustrated by a preface that feigns an ending (vale et para hospitium) before beginning again with the start of the prefatory epigram, and beginning for a third time with the two distiches found on the statue. The preface to book 9 thus stands as a paratext that violates its (para)textual boundaries even before it further complicates these barriers by engaging with the main structural motifs of book 9. As Lorenz has ably demonstrated, this preface's subject matter of the poet's statue acts as the introductory piece to book 9's collection of statues, which together provide a stable recurring motif for book 9's overall structure. ${ }^{19}$ These thematic links to the preface

16 Henriksén 2012, 4.

17 Henriksén 2012, 7 explains that vir clarissimus was a general term used to denote senatorial rank. The focus on fame in this passage offers another contrast here between Martial's status as a renowned poet and Avitus' relative obscurity. Toranius may be depicted as Martial's dearest friend (frater carissime) at 9 praef. 1, but he only appears once more in the Epigrams as a generic recipient of a dinner invitation at 5,78. His absence is as notable as Martial's presence.

18 Plin. epist. 3,21 plays a similar game by preserving some of Mart. 10,19. Cf. Henderson 2002, 47-58. 19 Lorenz 2003, 570 and passim. 
are further encouraged by lexical repetition later in the libellus: the great men singing about great things (Mart. 9 praef. ep. 7: maiores maiora sonent) forms a frame with the suitably-epic description of Domitian as the "greater" (Mart. 9,101,11: maior) Hercules towards the end of the book. ${ }^{20}$ This preface thus threatens its own paratextuality by foreshadowing motifs central to the book it precedes, which grants the preface a crucial role in the creation of a structural unity of the text. Nevertheless, by repurposing (or inventing) this self-commemorational poem from Avitus' library for book 9, Martial's preface questions the nature of textual materiality and reuse, and encourages the reader to question the physicality of the very words they see before them. The preface to Epigrams 9 breaks boundaries between the preface and the text, as well as the book and reality, but it paradoxically provides the reader with a way to interpret its place within the book from which it stresses separation.

The preface to book 9 breaks several paratextual and textual boundaries, but it is in his first preface that Martial establishes the trend of challenging his paratexts' liminality. Book 1's preface serves to establish the poet's stance and his expectations for the reader at the start of the Epigrams. Nevertheless its interaction with key themes within the book, alongside its inclusion of a poem within a prose letter, threatens the very boundaries the poet erects in marking out the preface as a separate textual entity to the rest of the book. In particular, his emphasis on introducing the book with a poem and his criticism of Cato Uticensis both exhibit the poet's fluid paratextuality:

Spero me secutum in libellis meis tale temperamentum ut de illis queri non possit quisquis de se bene senserit, cum salva infirmarum quoque personarum reverentia ludant; quae adeo antiquis auctoribus defuit ut nominibus non tantum veris abusi sint, sed et magnis. Mihi fama vilius constet et probetur in me novissimum ingenium. Absit a iocorum nostrorum simplicitate malignus interpres nec epigrammata mea inscribat: inprobe facit qui in alieno libro ingeniosus est. Lascivam verborum veritatem, id est epigrammaton linguam, excusarem, si meum esset exemplum: sic scribit Catullus, sic Marsus, sic Pedo, sic Gaetulicus, sic quicumque perlegitur. Si quis tamen tam ambitiose tristis est ut apud illum in nulla pagina latine loqui fas sit, potest epistula vel potius titulo contentus esse. Epigrammata illis scribuntur qui solent spectare Florales. Non intret Cato theatrum meum, aut si intraverit, spectet. Videor mihi meo iure facturus si epistulam versibus clusero:

Nosses iocosae dulce cum sacrum Florae

festosque lusus et licentiam volgi,

cur in theatrum, Cato severe, venisti?

An ideo tantum veneras, ut exires?

I hope that I have adopted in my little books such a moderation that no one who might think well of themselves could complain about them, since they play with safe reverence towards even the humblest personages-which ancient authors lacked so much that they abused not only real names but even great ones. May such fame remain cheaper to me and ingenuity be judged my last quality! May the malignant interpreter be absent from the frankness of my jokes and may he not write into my epigrams: he who is ingenious with another's book acts wrongfully. I would

20 Lorenz 2003, 579-580. 
excuse the playful truth of my words (i. e. epigram's tongue) if the paradigm was mine: but thus wrote Catullus, thus Marsus, thus Pedo, thus Gaetulicus, thus whomever is read through. Yet if anyone is so ostentatiously severe that it is not sanctioned to speak Latin on any column in his presence, he can be content with the letter or rather the title. Epigrams are written for those who usually watch Flora's games. May Cato not enter my theatre, or if he does enter, let him watch! I think I might rightly make an end to my letter in verse:

Although you knew the sweet ritual of joking Flora

And her festive games and the licence of the mob,

Why, severe Cato, did you come into the theatre?

or did you actually only come to go out?

(Mart. 1 praef.)

As with the preface to book 9, Martial's first preface toys with ideas of materiality and the unity of the book, and blurs the rigid line between text and paratext by transforming his preface's themes into verse with the inclusion of a prefatory epigram. The statement that Martial will "make an end to [his] letter in verse" (epistulam versibus clusero) announces the end of the prose epistle and the beginning of his poetry, but does not grant the prefatory epigram the status of the first poem of Epigrams 1, despite it being the first poem the reader encounters in the book. Indeed, the prefatory epigram summarises and develops the themes of the preface-the games of Flora (like epigrams in general/the Epigrams themselves) are the preserve of lewd behaviour and jokes, which Cato (and other potential moral critics of Martial) should have known about before entering. Any complaints against the Floralia (and, by association, Martial's Epigrams) could only be made by someone who wants to be seen complaining about morals, rather than for the sake of the mos maiorum. Martial's decision to make this quip in verse is especially significant since he has just said that those seeking to avoid his epigrams should leave at the letter or the title of the text (potest epistula vel potius titulo contentus esse); after reading the prefatory epigram the prudish reader is now trapped within the text like Cato, trapped within the theatre at the Floralia, and would become the object of mockery if they stood up and left in the manner of the infamous censor. ${ }^{21}$ Yet despite trapping the Catonian prude within the first epigram in the physical book, the prefatory epigram is itself still extra ordinem paginarum, and as such it is not a part of the main text of book 1 which begins with epigram $1,1{ }^{22}$ If the preface acts as a solid paratextual border the reader cannot have crossed the book's threshold by reading the prefatory epigram. Due to thematic bleeding, however, Martial's paratexts are not solid border lines but fluid zones of interaction with the text.

21 On Cato's exemplary departure from the Floralia, see Howell 1980, 100-101. Sen. epist. 97,8 and Val. Max. 2,10,8 describe Cato's departure from the theatre as an exemplary act.

22 Confusion in the manuscript tradition over whether Mart. 1,1 or 1 praef. ep. ought to come first demonstrates that this is a valid concern. Cf. Howell 1980, 102. I discuss the displacement of prefatory epigrams further below. 
As Fitzgerald remarks, "the first thing that we notice about Martial's first book is the profusion of first things"-Martial's first series of poems in the main body of the text serve as a series of introductions to the poet (Mart. 1,1), to his book (Mart. 1,2-1,3), to the emperor (Mart. 1,4-1,6), and to his patrons (Mart. 1,7-1,8) that complement the role of the preface. ${ }^{23}$ The textual borders between Martial's epigrams are already blurred, so rather than instigating a theoretical crisis point, the fluidity of Martial's paratextual prefaces engages with a key feature of his poetry. ${ }^{24}$ The preface and its prefatory epigram are merely another link in the chain of texts that constitutes Epigrams 1.

It is in the figure of Cato as an excessive moralist that Martial most clearly links the first preface with the themes of book 1's programmatic series, and which break down the boundary between text and paratext. When Martial begs Domitian to give the Epigrams a favourable reading in his capacity as the censor-the political office for which the Catonian family and Domitian were both renowned-his use of the term lusus (Mart. 1,4,7) recalls the prefatory epigram's criticism of Cato over the lusus at the Floralia (Mart. 1 praef. ep. 2). ${ }^{25}$ As in the preface, Martial beseeches his audience to read his work without undue malice or misplaced moralism. That Martial has set up Cato as a figure in opposition to himself here is soon made clear in epigram 1,8, where the poet expresses more favour for those "who can be praised without dying" (6: laudari qui sine morte potest), unlike Decianus' philosophical exemplars, Cato and Thrasea Paetus, who have "bought fame with easy blood" (5: facili redimit qui sanguine famam). This statement is a critique of Cato on its own, but it is significant that Martial's introduction of the poetic persona in 1,1 roots itself in the fact that he has achieved poetic renown while still alive (5: viventi decus atque sentienti), unlike the traditional poets who become famous long after their deaths (6), and unlike Thrasea and Cato whose fame was achieved through their deaths. That the appearances of Cato in book 1 also frame a list of exemplary suicides further links the Republican senator with discussions of death and fame, and further contrasts him with the poet's living renown. ${ }^{26}$ Cato's shade hangs heavily over the book, and the reader is frequently reminded (through lexical and thematic echoes) of the preface's content. By linking these poems together Martial works to create a central unity to the book (a 'Book Oneness' or a 'Buchein(s)heit', so to speak), but at the same time he fractures the boundary between preface and text. When Martial treats his prefaces in the same way as his poems, their paratextuality becomes much harder to define.

Indeed, one of the striking features of Martial's paratextual prefaces is their similarity to the programmatic epigrams found at the beginning of books without a preface. Each book of the Epigrams opens with a series of programmatic poems that

23 Fitzgerald 2007, 69.

24 Indeed, Genette 1997, 2 describes the paratext as "a zone without any hard and fast boundary".

25 On Domitian's perpetual censorship, see Jones 1992, 106.

26 Mart. 1,8 (Cato and Thrasea Paetus), 1,13 (Arria and Caecina Paetus), 1,42 (Porcia, Cato's daughter), and 1,78 (Festus and Cato). 
introduce the reader to the book's key themes and figures, irrespective of whether the book is prefaced by a letter, but in the books that do not include a prose preface these programmatic epigrams take on more of a prefatory role. Thus 3,1-3,2 and 3,4 explicitly tell the reader that the book is coming from Cisalpine Gaul in a manner that is remarkably similar to 12 praef. and 12,2's concerns over the book's innate Spanish identity. ${ }^{27}$ Epigrams 5,1-5,2 explain the lack of obscenity in the book in a similar way to 8 praef. and 8,1 . The introductory poems in the other books similarly lay out the topoi of their individual books, highlighting the praise of Domitian (Mart. 4,1-4,3; 6,1-6,4), the emperor's anticipated return to Rome (Mart. 7,1-7,8), the act of editing/revising the book (Mart. 10,1-10,2), and the work's overall Saturnalian spirit (Mart. 11,1-11,6). In each of these books the introductory role played by the prose preface is given to the programmatic epigrams instead as a way of introducing the reader to the book's setting and providing them with any necessary instructions on how to approach the text. In short, where prose prefaces are not present the epigrammatist employs a kind of verse preface instead.

Nevertheless, there is a key difference between prose and verse prefaces in Martial (besides the obvious difference of their form as prose or verse texts): their paratextuality. While Martial stresses that his epistulae are located extra ordinem paginarum there is no such emphasis of the separation of his verse prefaces from the rest of the book-these poems are to be considered very much a part of the text, as they are intra ordinem paginarum. The verse prefaces are physically connected to the rest of the text, within the prima pagina, and conceptually form a strongly connected part of the book's hermeneutic chain. By separating out his prose prefaces, by contrast, Martial creates a conceptual distance between prose preface and verse epigram, and creates a paratextual zone. While the verse prefaces are somewhat 'peritextual' in that they physically border the edge of the text, they are not separated from the rows of columns that enforce a sense of unity to the collection, nor are they visibly different to the other poems in their layout as poems instead of prose. ${ }^{28}$ When Martial writes prose prefaces he enforces some degree of separation between text and peritext, and divides the two from one another in a distinct way. Most significantly, Martial always chooses to end his prose prefaces with a letter, or to start the main text of his book with an epigram that follows on from the preface's themes. ${ }^{29}$ That he does so suggests that the best way for him to bridge the conceptual gap between preface and text (and to engage in fluid paratextuality) is to do so with a poem. The physical format of the main text intrudes into the paratext (in the case of the prefaces to book 1 and 9), or is resumed at the head of the prima pagina in books 2, 8, and 12 . Martial frustrates the liminality of his own

27 On the similarities between the opening of books 3 and 12, see Fusi 2006, 106 and 111-112, who focuses on Martial's wish not to appear foolish or barbaric in his writings from beyond Italy.

28 On the peritext, see n. 5 above.

29 Henriksén 2012, 3-4 makes similar observations. On the epigrammatic bridge (Brückenepigramm) between preface and text in Epigrams 8, see Schöffel 2002, 78. 
text's borders, but he can do so only by engaging with the physical aspect of the text. If there is some change to the physicality of the text, the paratextuality of the preface will also be affected.

\section{Chopping and Changing: The Impact of the Material Book on Paratextuality}

Alterations to the physical layout of the book and their accompanying changes to the layout of the text can have a significant impact on how the reader approaches and interprets the work. Extant classical texts have survived thousands of years of copying, editing, and change, and while changes to the text are made quite clear by the inclusion of an apparatus criticus in its critical edition, changes to the text's format and presentation are far more insidious. The modern presentation of a translation of Martial in the codex form, for instance, no longer has the physical characteristics of the bookroll to which the poet often alludes: the wooden roller (umbilici / cornua) around which the papyrus was wrapped is absent, and the turning of the page replaces the winding and rewinding of the papyrus which ordered the text into paginae. ${ }^{30}$ With the paginae no longer a standard feature of the textual medium, the prose prefaces are no longer represented physically as being extra ordinem paginarum, even if their conceptual distancing remains in the text. In the Loeb translation of the Epigrams, for example, this physical distancing of the paratext from its text is no longer enforced, and several of the prefaces spill over onto the same page as the first poem(s) of the book. ${ }^{31}$ The impact of these changes to the physical layout of the text have upon the reader's understanding of the text and paratext can be at once subtle and profound. The rest of this paper examines these changes, and explores how the fluidity of Martial's paratextual prefaces is frustrated or augmented by the materiality of the text.

A direct consequence of publishing multiple books of the Epigrams in the same volume is that this problematizes the role of a preface which no longer sits on the physical edge of the text. In modern editions of the Epigrams, the collation of these originally individual books ensures that the preface to book 2 appears between the end of book 1 and the beginning of book 2, reducing the physical distance between the two libelli. As I argue below, if the reader chooses to look backwards to book 1 as well as forwards to book 2, the paratext's borders become far less stable. The co-publication of Martial's libelli privileges the unity of the corpus over the individuality of the

30 On the cornua and umbilici, see Mart. 3,2,9; 4,89,2 and 11,107,1. On the physical characteristics of the ancient bookroll, see Johnson 2010, 17-22 and Winsbury 2009, 15-34.

31 This is the case for the prefaces to book 1, 9, and 12. Books 2 and 8 retain their distancing from the text with the turn of a page due to a happy accident of typesetting. 
book, which in turn subsumes the preface within this overarching collection of texts, textualising the paratext even further.

Book 2's preface opens by questioning the need for a preface at all. ${ }^{32}$ Martial's patron Decianus (whose words are put into his mouth by the poet) deems the letter a useless barrier that stands in the way of reading the actual epigrams, which he claims can speak for themselves in the role of the epistula (Mart. 2 praef. 1-8). Decianus continues to complain about the prefatory letter's relevance to an epigram book, to which Martial responds ironically by quipping that although he might have written an overly-long preface (13-14: quam longa epistula notium fueris habiturus) it is Decianus' responsibility for ensuring the brevity of the current letter, which will not weary the reader (16: non lassi prevenient).

The theme of a long libellus potentially causing boredom in the reader recurs across book 2, and frustrates this book's paratextual borders in the same fashion as book 1 and 9's prefaces. Epigram 2,1 opens the text with an address to the book, noting that although it could easily fit three hundred poems into the bookroll no one would read it through (1-2), but that despite its shorter text many will still consider the libellus too long (12: longus). In 2,6 these concerns are realised when Severus-one of the poet's erstwhile fans-is caught "dragging out long yawns" (4: longas trahis oscitationes), which combines the preface's two concerns over length and boredom, and draws the preface and the book more closely together. ${ }^{33}$ Later on in the book Martial again brings up the concern over poem and book length by responding to Cosconius' complaint at 2,77,1 that Martial produces longa epigrammata. The pun that ends this poem-“but you, Cosconius, make distiches long” (8: sed tu, Cosconi, disticha longa facis)-revolves around a metrical joke on the target's name that further develops the theme of appropriate length; each syllable of Cosconi is long, and ends the spondaic hemistych of the pentameter immediately before a caesura, after which the rest of the line is dactylic. 'Cosconius' really does make an epigram long. ${ }^{34}$ These epigrams, which use the same language to discuss criticisms of Martial's work, extend the theme of the reader's boredom from book 2's preface, and disrupt the border between paratext and text.

As with the prefaces to books 1 and 9, the theme of Martial's second preface bleeds into the rest of book 2, but this paratext also repeats a theme from the end of the previous libellus. Book 1 ends with a quick couplet stating that "for whomever it is not enough to have read one hundred epigrams there is never, Caedicianus, enough of

32 Johanssen 2006, 81 deems this a "Meta-praefatio", Williams 2004, 17 considers Mart. 2 praef. "light play on the grand tradition of the recusatio". As Magritte might have put it: ceci n'est pas une lettre. 33 Cf. Williams 2004, 18. Pace Johanssen 2006, 84, who views this thematic and lexical link between the preface and the book as "nicht mehr als eine kurze lineare Anknüpfung".

34 The metre of this pentameter line runs as follows: $--|---|||-\cup|-\cup-|-$. Cosconius is depicted as a poor epigrammatist at Mart. 3,69,7, which suggests that this joke is also poetological: Cosconius writes (facit) long poems, but his name also makes (facit) poems long. 
a bad thing." 35 This epigram appears after the hundredth poem of the book, and so jokes at its own poor nature by setting a critical limit on the length of the work. By developing the same theme of book length in 2 praef., however, and by including a reference to hundreds of poems being a bad thing in 2,1,1, Martial uses his preface to bridge the gap between these two books. Thematic continuity is not a problem by itself-narrative texts frequently carry on from one book's end to the other's beginning as a way of creating a more satisfying sense of unity for the overall text-but the use of a paratext that self-identifies as belonging somewhere before book 2's first pagina creates complications. ${ }^{36}$ Martial's second preface encourages the reader to question where one book ends and another begins; if the preface is another link in an unending chain of epigrams it cannot be truly paratextual. Martial's work is typified by its paradoxical nature-scholars have noted his work's penchant for harsh juxtapositions that threaten disunity while also creating a sense of unity-but the paradox of Martial's textualised prefaces is enhanced by the way the text is presented to the reader. ${ }^{37}$ In antiquity Martial's books would have existed on separate papyri that firmly established the edges of the book with empty, textless space. Modern editions of Martial, however, create a larger sense of a corpus by printing multiple books in the same volume. In the Loeb translation of Martial into English, for instance, Martial's Liber Spectaculorum is accompanied by Epigrams $1-5$ in the first volume; volume 2 contains books 6-10; and volume 3 holds books 11-12 as well as the Xenia and Apophoreta. Not only does this collation reorder the publication dates of Martial's work (as the Xenia and Apophoreta are dated to the period between the publication of the Liber Spectaculorum and Epigrams 1), it also reduces the physical distance between works in the same volume. ${ }^{38}$ Whereas in antiquity the closure at the end of the book was reinforced by the reader's physical act of rewinding the scroll for its next use (like the modern, albeit now defunct, cassette tape), in modernity this closural reinforcement between Martial's individual books is delayed until the end of the Loeb volume. ${ }^{39}$ Thus books 5 and 6 might seem 'further apart' to the modern reader because progressing from one book to the other involves shutting one volume to open the next, whereas books 3 and 4 might feel conceptually 'closer' because of their physical proximity. In this way, the physical layout of the Loeb edition compounds the paratextual paradox of Martial's second preface, which is situated on the same physical document as the book it precedes (book 2) and the book whose theme it continues (book 1).

35 Mart. 1,118.

36 Ovid ends met. 2 with a description of the rape of Europa, which then continues at the start of met. 3 , for instance.

37 For Fitzgerald 2007, 198 Martial's books are “impossible wholes”, for Rimell 2008, 156 his work "neatly performs the contradiction of ordered disorder, or disordered order that epitomises the Saturnalia."

38 On the dating of Martial's corpus, see Fowler 1995, 32-33.

39 Van Sickle 1980, 6. 
How the reader perceives the individuality of Epigrams 2 is crucial to their perception of the text itself, and this is best exemplified by an examination of the book's scholarly reception. In the 19th century Friedländer advanced the (now unpopular) view that books 1 and 2 were published together in the same papyrus scroll, based primarily on epigram 3,1, 3's comment to the reader that "you are reading this [i. e. book 3] and perhaps you praise the previous book (librum priorem)”. For Friedländer, the appearance of librum priorem in the singular form only made sense if the liber to which the poet alluded was a combined edition of books 1 and $2 .^{40}$ The argument itself is untenable, not least because this vague reference to a single prior liber could easily refer to the immediately-preceding book rather than a collected volume, and because 2,93 jokes around with the idea of being the second book coming after the first, currently absent, book. ${ }^{41}$ Nevertheless, this argument demonstrates the significance of the presentation of the two individual books on the same scroll/book. When these two books are published as one combined document (let alone when they are published alongside the rest of the Epigrams), the conceptual divide between them is reduced dramatically, as the 'end' of one book physically brushes against the beginning of the next. The presence of book 1 immediately in front of book 2 also reduces the potency of the paratextual border between book 2 and its preface; book 1, like 2 praef., is extra ordinem paginarum, and the preface takes on a role more as a bridge between these books than as an introduction to book 2. In modern editions of the Epigrams the fluid paratextuality of Martial's prose prefaces is intensified by their physical proximity to the other books in the corpus. Book borders are still present, but their impact is reduced dramatically by the delayed closure of the work to the end of the combined volume.

The impact of the physical representation of the text on Martial's paratextual prefaces is most clearly evidenced by their omission, whether in the transmission of the manuscripts or in modern practices of anthologisation. Most modern translations anthologise Martial and provide a representative selection of his work, partly because the poet wrote over fifteen hundred poems over the course of his career, which a single book could not contain comfortably. In this physical manipulation of the text it is the prefaces that are most conspicuously absent-students using the Watsons' commentary on select epigrams of Martial will only find reference to these paratexts in the introduction, and until recently translations of Martial regularly omitted several of the prefaces due to the spatial constraints of a single volume selection of the poems. ${ }^{42}$ Anthologisation makes Martial more accessible to a modern audience, but this takes

40 Friedländer 1886, ad loc.

41 See Citroni 1975, xiv-xviii, Fusi 2006, 109, Howell 1980, 5-6 and Williams 2004, 281-282. Rimell 2008, 122-139 demonstrates how Mart. 2,93 forms part of book 2's larger programme of playing with numbers and marking itself out as the second book in the corpus.

42 Watson/Watson 2003, 30. Nisbet 2015 omits only Mart. 2 praef., while Holzberg 2008 only includes 1 praef. and 12 praef. 
place at the expense of an understanding of the text's overall structure. As such, many modern readers have little knowledge of the prefaces at all; for them the text is an assorted collection of poems, and the overarching structure of the text is difficult to discern. Indeed, if a translator is to present a selection of the Epigrams to their reader the prefaces constitute a significant challenge-as objects extra ordinem paginarum these letters are technically not a part of the text and may not be deemed representative of Martial's epigrammatic work. The prefaces' paratextuality makes them particularly vulnerable to loss during textual transmission.

That the prefaces are common targets for omission is clear from their frequent absence or alteration in the manuscript tradition. Martial's manuscript tradition is relatively stable for a classical text, and has been ordered into three main families $-\alpha$, $\beta$, and $\gamma$-from which critical editions of the text can be established without too much scholarly debate. ${ }^{43}$ Given the relative stability of this tradition, it is noteworthy that the prefaces are often omitted or altered. The $y$ family omits the prefaces to book 2 and 9, while the $\beta$ family does not transmit book 8's preface. ${ }^{44}$ Likewise, only the $y$ family preserves a superscript announcing that the first preface is addressed to the poet's reader, and despite the likelihood that this titulum is authentic modern texts do not print it. ${ }^{45}$ While the reader of Martial's first preface still reads this paratext as a general introduction to book 1 that was written for their benefit, the addition of a superscript would make the preface's role more overt and would frame the reader's approach to the text in a slightly more nuanced manner. Whether or not one believes that the first preface should have a superscript, its potential absence demonstrates the change to a reader's approach to the text when part of the paratext has been omitted. As with modern anthologisation of the Epigrams, it appears that the status of these prefaces as items somewhere beyond the text caused conceptual problems for those transmitting the whole work. This issue even caused White to doubt that the preface to book 2 belonged to the published work, and he argued that it was instead attached to the text as a vestigial remnant of a patron's individual copy. ${ }^{46}$ For him, and for some of those who have copied the text over the last two thousand years, it is this (para)textual otherness that denies the prefaces a place in Martial's corpus.

Another result of the scholarly desire to classify and define the text in modern editions is that Martial's prefaces and prefatory epigrams are labelled as either pa-

43 For a particularly clear discussion of Martial's MS tradition, see Williams 2004, 12-14. Henriksén 2012, xliii-xlv and Schöffel 2002, 11-14 both provide useful summaries as well.

44 Williams 2004, 18.

45 Howell 1980, 95 thinks the titulum genuine but does not print it. Citroni 1975, 4 is more wary, but notes that the $y$ family may be correct. Shackleton Bailey 1990, 14 also acknowledges the titulum's appearance but does not include it.

46 So White 1974, 58. In response, Fowler 1995, 51 argues that the Epigrams are not a "social log" of interactions between patron and client, but instead construct their own social context for the reader to enjoy. 
ratext or text, with little room for the liminality of their status. The modern system of numbering the poems-a feature that is absent from the ancient text-makes it easier to reference specific epigrams in the corpus, but it also has a direct consequence of explicitly labelling Martial's prefaces as paratextual, and concretely defining the exact opening of the text as the first numbered epigram in the libellus. Only Martial's Xenia and Apophoreta originally included lemmata to introduce the epigrams within their books, which served an explanatory function for the more riddling entries. ${ }^{47}$ In a numbered edition of the text, a debate arises over whether 1,1 or 1 praef. ep. is the first poem of the Epigrams, but this debate would not have been created by the text's layout in antiquity.

In the case of book 8, it even appears that this modern system of labelling the poems has transferred a prefatory epigram from the paratext into the borders of the text itself, separating a prefatory epigram from its letter. After five books that open with programmatic poems, book 8 begins with a preface explaining the moral rectitude of book 8 and its absence of obscene material. Like in the first preface, Martial then declares his desire to make his views clearer to the reader by announcing this change "on the very boundary of this little book in the briefest of epigrams" (Mart. 8 praef. 19-20: in ipso libelli huius limine profiteri brevissimo placuit epigrammate). Bizarrely, the preface then closes and the reader must wait until epigram 8,1 to read this poem, unlike in the first book where the prefatory epigram is displayed comfortably within the preface's boundaries. The epigram does sit on the very border of the book, but its language specifies a level of anticipation for the book from a paratextual perspective. By moving this epigram from the preface to the text, the overall tone of 8,1 has shifted:

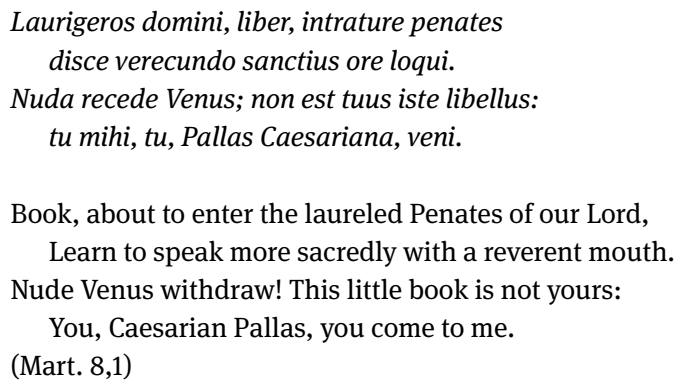

A number of features of this poem encourage a reading of 8,1 as a prefatory epigram that belongs in the borders of the paratext. The language and style of 8,1 set this poem up as a parallel to the prefatory epigram of the first preface, which also discussed

47 Leary 1996, 58. Translations that supply thematic lemmata for the individual poems of the Epigrams, such as Holzberg 2008, provide the reader more with the translator's own interpretation than a faithful rendition of the original text's layout. Exposition can be useful for a modern audience, however, as with the similar case of explanatory footnotes seen in the Loeb edition of the text. 
the moral implications of the poet's work. Both poems act as gatekeepers to the text, evicting opposing kinds of readers; in 1 praef. ep. it is the Catonian moralist who is warned away, whereas here the lascivious figure of Venus (a metonym for the poet's lascivious verse) is evicted in favour of virginal Minerva's probity. ${ }^{48}$ The language of holiness (1-2: penates, disce verecundo sanctius ore) also develops the topics of the emperor's divine sanctity and the book's representation as a temple that were established within the preface-Martial's book understands that "one should not approach temples unless cleansed by religious purification" (Mart. 8 praef. 16-17: meminerit non nisi religiosa purificatione lustratos accedere ad templa debere). ${ }^{49}$ This approach is anticipated in epigram 8,1, which represents itself as a warning to the book (and so the reader) that is about to cross the threshold at a temple (1: intrature). But when placed at the head of book 8 , epigram 8,1 has already crossed this threshold; if this poem is understood as a prefatory epigram instead (i.e. as Mart. 8 praef. ep.), then its address for the reader and the book about to enter a sacred space is far more effective, and the future participle makes more grammatical sense. As with the Catonian prude in 1 praef. ep. who is tricked into crossing the boundary from preface to text when the poet chooses to end his letter in verse, the prefatory reader of 8,1 is warned against entering the poetry book's temple by a poem. Martial constantly plays with ideas of paratextuality in his prefaces, but it would be unprecedented for Martial to refer to a poem in his preface without including it as a prefatory epigram. Books 1 and 9 both include the poem they describe in the preface within the paratext, while books 2 and 12 both open with poems that continue themes from the preface without an overt reference to them in the preface itself. If epigram 8,1 remains within the text's borders, it stands as an outlier from Martial's normal practice.

The content and style of the programmatic poems of book 8 also suggest that epigram 8,1 is potentially a poem out of place. If epigram 8,1 is moved to the paratext and becomes its prefatory epigram instead of the first programmatic poem, 8,2's opening image of Janus-the two-headed liminal god of boundaries-provides an appropriate depiction of the border the reader has just crossed by opening the book and moving from paratext to text. ${ }^{50}$ Schöffel, the book's commentator, sees 8,1 as a "bridge epigram" (Brückenepigramm) that consciously blurs the borders between text and preface, and as such he is wary not to argue for 8,1 as a prefatory epigram despite acknowledging the appearance of Janus in $8,2 .{ }^{51}$ Nevertheless, there is a significant

48 Johanssen 2006, 94 draws a further parallel between these prefaces: the adjective severus is used to describe writers of epigram at Mart. 8 praef. 11 and Cato at 1 praef. ep. 3.

49 For this poem as an invocation of divinity and an imitation of inscriptions at religious sites forbidding sacrilegious acts, see Schöffel 2002, 79 and 84.

50 Sharrock 2009, 22 observes that Janus appears as a prefatory figure in Roman Comedy, a role he also plays in Ov. fast. 1,63-288.

51 Schöffel 2002, 78. Johanssen 2006, 90 views the relationship between Mart. 8 praef. and 8,1 as identical to that between 2 praef. and 2,1, despite 8 praef. 18-20's explicit introduction of the poem. 
impact on the reader's perception of the book's opening if this poem remains intra rather than extra ordinem paginarum. Furthermore, the order of the opening poems of book 8 also echoes the order of the opening poems of book 1 if 8,1 is moved back into the preface. The first poem of both books is written in hendecasyllables (Mart. 1,1 and 8,2 ) and then followed by a metapoetic poem concerning the physical book (Mart. 1,2 and 8,3). It is also striking to see a similarity between the opening of books 5 and 8 , as Schöffel notes, with the first three poems acting out the same functions: there is an address and well-wishing for the emperor (Mart. 5,1 and 8,2), a metapoetic poem discussing the book itself (Mart. 5,2 and 8,3), and then homage is paid to the emperor's military prowess (Mart. 5,3 and 8,4). ${ }^{52}$ Whether or not one reorders the numbering of book 8, the programmatic series reflects standard opening practices for Martial's libelli. But if 8,1 is moved back to the preface these parallels to the other books become more evident.

To some extent, however, one should not attempt to reconstruct the 'original' text by re-dividing the modern book. Prefatory epigrams may once have been positioned extra ordinem paginarum, but there is ultimately no way of proving the original layout of the text due to the simple fact that the original text no longer survives. What remains is to analyse the text as it is extant, while staying aware of how the text's physical presentation might encourage new interpretations of the preface's paratextuality. Although 8,2's subject matter of Janus the god of boundaries is apt for the opening poem of a book that stands on the boundaries highlighted by the preface's self-referential limen (Mart. 8 praef. 19), the poem also forms part of an opening catalogue of divinities. The book's preface opens with Domitian (described as a deus at the end of 7,99) in all his divine glory; pairs him with Athena-his patron deity-whilst rejecting Venus at 8,$1 ;^{53}$ then requests Janus' goodwill to Domitian at 8,2; offers a recusatio (pre-empted by the receding Venus at 8,1) to the Muses at 8,3; and at 8,4 returns to Domitian, who is worshipped by the gods themselves (4: sed faciunt ipsi nunc, puto, sacra dei). Whether or not 8,1 is judged as a separate poem the thematic sequence still carries on, inexorably drawing the reader into the book and establishing the emperor as a divine figure surrounded by significant divinities. When viewing the text from a thematic point of view the individuality of each epigram is less important-the boundaries of each poem blur together to form the same larger concept (here the association of the emperor with the divine). For book 8 the preface is yet another link in the programmatic chain, as much a part of the text from which it stands apart; Martial's fluid paratextuality is too effective at blurring the paratextual boundary between preface and text to allow one definitive reading of the preface and its prefatory epigram.

Ultimately, Martial's prose prefaces act in much the same way as his epigramsthey establish ideas for the poems they precede, and encourage the unity of the text by

52 Schöffel 2002, 78 n.3.

53 On Domitian's patron deity, see Suet. Dom. 15,2-3 and Jones 1992, 100. 
preparing for the recurrence of key words and themes within the book (Mart. 2 praef. and 12 praef.). A reader's approach to a text affects their interpretation of it, however, and changes to the reader's perception of the text are aided by material changes to the text. All texts change over time, but classical works in particular have survived thousands of years of copying, editing, and changes to their material representation. It should never be forgotten that modern critical edition of ancient texts pretend a level of stability for a work whose extant witnesses usually date to hundreds-if not thousands-of years after its initial creation. When Martial's reader unfurled the scroll and found columns of poems, the statement that the preface and its prefatory epigrams lay extra ordinem paginarum (Mart. 2 praef. 15-16 and 9 praef. 1-2) would have reinforced the visual distinction between text and paratext that was created by their physical separation. When the modern reader, or the reader of an ancient codex or medieval manuscript, turns the page to move between individual books of the Epigrams, this distinction mostly disappears. Physical changes to the format (unfurling the scroll instead of turning the page; keeping the libelli in the same material book rather than separating them out into individual editions) can result in conceptual shifts to their interpretation. The effect of these material changes to the book on their prefaces is to enhance their already-fluid paratextuality-the ending of a book is far less finite when its borders physically brush against the beginning of the next libellus.

Most significantly, this paratextual fluidity is brought about by a combination of material and textual factors. Martial's prefaces encourage questions about their paratextuality by playing with their own liminality; while the poet stresses that these prose letters are beyond the borders of the text, the inclusion of prefatory epigrams within their own borders (Mart. 1 praef.; 9 praef.), or the announcement of an upcoming epigram (Mart. 8 praef.), problematizes the idea of crossing the threshold between paratext and text. Furthermore, Martial's treatment of his prose works in an identical manner to his verse further reduces the distinction between his prefaces and epigrams that was enforced by their physical layout on the scroll. Martial's prefaces have always been both textual and paratextual elements in the Epigrams, but more recent alterations to the layout of the text on the page have made these prefaces more textual than they may once have been.

\section{Bibliography}

Anderson, Robert D./Parsons, Peter J./Nisbet, Robin G. M. (1979), “Elegiacs by Gallus from Qașr Ibrîm”, in: The Journal of Roman Studies 69, 125-155.

Blake, Sarah (2014), "Text, Book, and the Textbook: Martial's Experiments in the Codex", in: Ramus 43 (1), 67-93.

Citroni, Mario (1975), M. Valerii Martialis epigrammaton liber primus, ed., introd. and comm. by M. C., Florence.

Fitzgerald, William (2007), Martial: The World of the Epigram, Chicago/London. 
Friedländer, Ludwig (1886), M. Valerii Martialis epigrammaton libri, ed. and comm. by L. F., Leipzig. Fowler, Don P. (1995), “Martial and the Book”, in: Ramus 24 (1), 31-58.

Fusi, Alessandro (2006), M. Valerii Martialis epigrammaton liber tertius, ed., introd., trans. and comm. by A. F. (Spudasmata 108), Hildesheim.

Genette, Gérard (1997), Paratexts: Thresholds of Interpretation, trans. by Jane E. Lewin (Literature, Culture, Theory 20), Cambridge.

Henderson, John (2002), Pliny's Statue: The Letters, Self-Portraiture and Classical Art, Exeter.

Henriksén, Christer (2012), A Commentary on Martial: Epigrams Book 9, Oxford.

Holzberg, Niklas (2008), Martial: Epigramme, introd. and trans. by N. H., Stuttgart.

Howell, Peter (1980), A Commentary on Book One of the Epigrams of Martial, ed., introd., trans. and comm. by P. H., London.

Jansen, Laura (2014), “Introduction: Approaches to Roman Paratextuality”, in: Laura Jansen (ed.), The Roman Paratext, Cambridge, 1-18.

Janson, Tore (1964), Latin Prose Prefaces: Studies in Literary Conventions, Diss. Stockholm University.

Johanssen, Nina (2006), Dichter über ihre Gedichte: die Prosavorreden in den 'Epigrammaton libri' Martials und in den 'Silvae' des Statius (Hypomnemata 166), Göttingen.

Johnson, William A. (2004), Bookrolls and Scribes in Oxyrhynchus, Toronto.

Johnson, William A. (2010), Readers and Reading Culture in the High Roman Empire: A Study of Elite Communities, Oxford.

Jones, Brian W. (1992), The Emperor Domitian, London.

Leary, Timothy J. (1996), Martial Book XIV: The Apophoreta, London.

Lorenz, Sven (2003), “Martial, Herkules und Domitian: Büsten, Statuetten und Statuen im Epigrammaton Liber Nonus", in: Mnemosyne 56 (5), 566-584.

Newlands, Carole E. (2009), "Statius' Prose Prefaces”, in: Materiali e discussioni per l'analisi dei testi classici 61, 229-242.

Nisbet, Gideon (2015), Martial: Epigrams, Introduction and Transmission, Oxford.

Parker, Grant (2014), “Tarda Solacia: Liminal Temporalities of Statius' Prose Prefaces”, in: Laura Jansen (ed.), The Roman Paratext, Cambridge, 112-128.

Rimell, Victoria (2008), Martial's Rome: Empire and the Ideology of Epigram, Cambridge.

Roman, Luke (2001), “Literary Materiality in Martial's 'Epigrams”, in: The Journal of Roman Studies 91, 113-145.

Schöffel, Christian (2002), Martial, Buch 8: Einleitung, Text, Übersetzung, Kommentar (Palingenesia 77), Stuttgart.

Shackleton Bailey, David R. (1990), M. Valerii Martialis Epigrammata, ed. and introd. by D. R. S. B, Leipzig.

Sharrock, Alison (2009), Reading Roman Comedy: Poetics and Playfulness in Plautus and Terence, Cambridge.

Van Sickle, John (1980), “The Book-Roll and Some Conventions of the Poetic Book”, in: Arethusa 13 (1), 5-42.

Watson, Lindsay/Watson, Patricia (2003), Martial: Select Epigrams, ed., introd. and comm. by L. W. and P. W., Cambridge.

White, Peter (1974), "The Presentation and Dedication of the Silvae and the Epigrams", in: The Journal of Roman Studies 64, 40-61.

Williams, Craig A. (2004), Martial: Epigrams Book Two, ed., introd., trans. and comm. by C. A. W., Oxford.

Winsbury, Rex (2009), The Roman Book: Books, Publishing and Performance in Classical Rome, London. 